\title{
O RECENTE ATIVISMO JUDICIAL NO BRASIL: A DESAPOSENTAÇÃO SOB A ÓTICA DE JOGOS DISCURSIVOS
}

\section{THE RECENT JUDICIAL ACTIVISM IN BRAZIL: DESAPOSENTAÇÃO FROM THE PERSPECTIVE OF DISCURSIVE GAMES}

\author{
${ }^{1}$ Mônica da Silva Cruz \\ ${ }^{2}$ Viviane Freitas Perdigao Lima
}

\section{RESUMO}

A desaposentação é um tema que há algum tempo vem suscitando debates calorosos no campo jurídico brasileiro. As decisões a ela relacionadas configuram-se como ativismo judicial, na medida em que são dadas pela interferência dos Tribunais na efetividade desse direito. Este artigo tem por finalidade analisar alguns movimentos discursivos que se estabelecem em discussões sobre o conceito de ativismo judicial, tomando como exemplo a desaposentação, no Brasil. Analisam-se, inicialmente, aspectos discursivos da constituição histórica do conceito de ativismo judicial. Em seguida, discorre-se sobre as lutas que se instauram em torno dos sentidos edificados no conceito de desaposentação, considerando que todo saber se faz a partir de jogos de discursos tomados como um conjunto de estratégias que fazem parte de práticas sociais, nascidas nas tramas da história. O referencial teórico pauta-se em princípios foucaultianos acerca dos conceitos de discurso, enunciado e sua ordem (FOUCAULT, 1996; 2008). Metodologicamente avaliam-se conceitos de ativismo judicial, discursos parlamentares e judiciais. Enfim, verifica-se que o discurso ativista, na efetivação de direitos é permeado por jogos estratégicos, de ação e reação, de dominação e esquiva, como também de lutas.

Palavras-chave: Análise do discurso, Ativismo judicial, Desaposentação

\footnotetext{
${ }^{1}$ Doutora em Linguística pela Universidade Estadual Paulista Julio de Mesquita Filho - UNESP, São Paulo (Brasil). Professora de Direito pela Universidade Federal do Maranhão - UFMA, Maranhão (Brasil). E-mail: monicasc.cruz@ig.com.br

${ }^{2}$ Mestre em Direito e Instituições do Sistema de Justiça pela Universidade Federal do Maranhão - UFMA, Maranhão (Brasil). Assessoria Jurídica pela Obras Sociais Lar de José - OSLJ, (Brasil).

E-mail: viperdigao@gmail.com
} 


\begin{abstract}
The desaposentação is a topic that for some time has raised heated debate in the Brazilian legal field. Decisions related to it constitute itself as judicial activism, in that are given by the interference of the courts in the effectiveness of this right. This article aims to analyze some discursive movements that are established in discussions on the concept of judicial activism, taking as an example the desaposentação in Brazil. It analyzes initially discursive aspects of the historical constitution of the concept of judicial activism. Then it talks about the struggles that are established around the senses built on the concept of desaposentação considering that all knowledge is made from games of speeches taken as a set of strategies that are part of social practices born in the plots history. The theoretical framework is guided in Foucault's principles speech about the concepts, wording and your order (Foucault, 1996; 2008).

Methodologically assess up concepts of judicial activism, judicial and parliamentary speeches. At last, it turns out that the activist discourse in enforcing rights is permeated by strategy games, action and reaction, of domination and avoidance, as well as struggles.
\end{abstract}

Keywords: Discourse analysis, Judicial activism, Desaposentação 


\section{INTRODUÇÃO}

Carros de luxo, aeronaves e embarcações podem ser aproveitados pelas autoridades em favor da sociedade, desde que comprovado o interesse público ou social e o juízo competente assim autorize, é o que prevê a chamada Lei de Drogas (Lei n. 11.343/06). Percebe-se que a própria lei já garante ao Judiciário um gestor de finalidade social.

Daí, quando os órgãos judiciais resolvem conflitos entre particulares, determinando, por exemplo, o pagamento de uma indenização por quem causou um acidente, punindo um homicida, resolvendo um divórcio, um dissídio coletivo trabalhista, conflitos de vizinhança ou o despejo de um imóvel, não há que se falar em polêmica sobre a legitimidade do poder que exerce, mesmo porque está incursionando-se no núcleo essencial de suas funções constitucionais.

Até neste ponto não se observa nada de anormal, mas o debate ganha fôlego quando uma parcela de poder político passa a ser exercido pelo Judiciário e este realiza mudanças significativas em políticas públicas, sobretudo, em políticas estabelecidas por outras instituições.

A questão ganha muita complexidade quando tal poder atua em disputas que envolvem a validade de atos estatais ou nas quais o Estado, como outros órgãos de Poder, seja parte. É o que ocorre quando declara inconstitucional a cobrança de um tributo, por exemplo, a taxa de lixo, suspende a execução de uma obra pública por questões ambientais e aplica o chamado "Termo de Ajustamento de Conduta-TAC", determina a um hospital público que realize tratamento experimental em paciente que solicitou tal providência em juízo. Mas algo que tem chamado atenção dos juízes federais, no contexto atual, é deferir pedido de desaposentação, mesmo não havendo em tal caso qualquer lei expressa do Congresso Nacional ou Decreto Presidencial que autorize a medida.

Nestes casos, juízes e tribunais sobrepõem sua vontade a de agentes públicos de outros Poderes, eleitos ou nomeados para o fim específico de fazerem leis, construírem estradas ou definirem as políticas de saúde.

Para blindar a atuação judicial da influência imprópria da política, a cultura jurídica tradicional sempre se utilizou de dois grandes instrumentos: a independência do Judiciário em relação aos órgãos propriamente políticos de governo; e a vinculação ao direito, pela qual juízes e tribunais têm sua atuação determinada pela Constituição e pelas leis.

Órgãos judiciais, ensina o conhecimento convencional da prática jurídica do século XXI, não apresentam vontade própria, mas concretizam a vontade política majoritária 
manifestada pelo constituinte originário ou pelo legislador reformador. O mecanismo de interpretar e aplicar normas jurídicas é concretizado por um conjunto de princípios, regras, convenções, conceitos e práticas que dão consistência à ciência do direito ou dogmática jurídica. Este é, portanto, o discurso padrão-oficial: juízes ocupam lugares independentes da política e limitam-se a aplicar o direito vigente, de acordo com critérios aceitos pela comunidade jurídica.

Contudo, observa-se que diante de todo o discurso na proteção e efetividade de direitos fundamentais que explicitamente não estão protegidos em leis ou decretos existem atravessamentos de variada ordem, pois os discursos produzidos numa sociedade não são livres, já afirmava Foucault (1996), em A ordem do discurso. Nas reflexões de Michel Foucault, existe uma cadeia de situações, incluindo sujeitos que enunciam e instituições de onde eles enunciam, que controlam e selecionam e fazem os discursos circularem de certa maneira e não de outra. Assim, no discurso proativo do Poder Judiciário também há um controle, pois sua materialidade pode ser vista por outros Poderes como temível ferramenta.

Este artigo busca reflexões sobre o discurso ativista e como está sendo construído o direito social à desaposentação nas diferentes formas de poder (mobilizadas pelos próprios doutrinadores, pelo Poder Legislativo, órgãos do Executivo, pelo Poder Judiciário) que ora defendem e ora tentam rechaçar a construção do trabalho intenso e efetivo do Poder Judiciário que vem atuando em espaços vazios deixados por outros Poderes. Desse modo, este trabalho busca compreender um conjunto de estratégias que põe em jogo a luta pelo poder, sob o argumento de atender os interesses sociais em conflitos no conceito de ativismo judicial tomando-se como exemplo a desaposentação.

Adotam-se como aparato teórico-metodológico desta análise algumas reflexões de análise de discurso, proposta por Michel Foucault (1996; 2008), a qual permite observar, por meio dos vestígios deixados no próprio discurso, relações de sentido e de poder. Assim, busca-se avaliar o dizível e o não dizível do discurso sobre a desaposentação, o modo como esse discurso se filia a diferentes instâncias discursivas, os processos de identificação e os jogos simbólicos estabelecidos entre sujeitos e verdades.

Metodologicamente, analisam-se, no âmbito do Poder Legislativo, discursos de parlamentares sobre o projeto da desaposentação obtidos diretamente dos sítios eletrônicos de ambas as casas legislativas federais. No que tange ao Poder Executivo, avaliam-se publicações e discursos oficiais, também obtidos diretamente no endereço virtual de entidades que pesquisam aquele poder. Quanto ao Poder Judiciário se trouxe jurisprudência pacífica do 
Superior Tribunal de Justiça cuja ementa do julgado foi obtida pelos mesmos mecanismos acima relatados.

O texto está dividido em duas seções: a primeira traz reflexões sobre a construção de sentidos em torno do conceito de ativismo judicial. Na segunda, a discussão concentra-se em analisar a construção do discurso do Poder Executivo para se evitar um possível ativismo, Poder Legislativo para construir o direito à desaposentação e do Poder Judiciário no deferimento de tal direito. Por fim, conclui-se que como todo discurso, o discurso ativista não é livre. Nele há uma cadeia de situações que o controla e o seleciona.

\section{O ATIVISMO JUDICIAL COMO UNIDADE CENTRAL DE DISCURSOS}

Na esteira de Michel Foucault (2008), considera-se que os discursos são elementos formadores de uma sociedade e por meio deles todas as verdades de uma época são instauradas e se fazem valer. Neste texto, o propósito é tecer algumas reflexões em torno da desaposentação, como emblema de ativismo judicial, entendendo inicialmente que o enunciado é elemento fundamental de todo discurso e que este não existe sem história ou sem sujeito. Desse modo, a expressão ativismo judicial será percebida como um enunciado, isto é, como unidade de discursos, conforme proposto por Michel Foucault (2008), em A Arqueologia do saber.

O discurso, nessa obra, é compreendido como um conjunto de enunciados que se organiza em torno de uma mesma formação discursiva. Foucault (2008, p. 133-134) descreve a formação discursiva como "grupos de enunciados, isto é, conjuntos de performances verbais" que estão ligadas entre si no nível dos enunciados, constituindo-se no "sistema enunciativo geral ao qual obedece um grupo de performances verbais". Em outras palavras, uma formação discursiva diz respeito "ao que pode e ao que deve ser dito" por um sujeito em certas circunstâncias.

Consoante Foucault:

O enunciado não é, pois, uma estrutura (isto é, um conjunto de relações entre elementos variáveis, autorizando assim um número talvez infinito de modelos concretos); é uma função de existência que pertence, exclusivamente, aos signos, e a partir da qual se pode decidir, em seguida, pela análise ou pela intuição, se eles "fazem sentido" ou não, segundo que regra se sucedem ou se justapõem, de que são signos, e que espécie de ato se encontra realizado por sua formulação (oral ou escrita). (FOUCAULT, 2008, p. 98). 
Para o autor não há critérios estruturais de unidade para definir o enunciado, pois ele "não é em si mesmo uma unidade, mas sim uma função que cruza um domínio de estruturas e de unidades possíveis e que faz com que apareçam, com conteúdos concretos, no tempo e no espaço" (FOUCAULT, 2008, p.98). Segundo ele, é essa função que é preciso descrever, ou seja, como ela é exercida, em que condições, quais regras que a controlam e em que campo se realiza. Também nessa dimensão é preciso perscrutar as redes de memória, os sentidos e as filiações históricas a que o enunciado se associa.

Assim sendo, o enunciado não atravessa os séculos e é usado conforme a época, ele é inventado em cada época (FOUCAULT, 2008, p. 25). Por essa razão, o enunciado está sempre em correlação, ou seja, nunca está isolado em um discurso no qual se busca o sentido numa continuidade. É sempre vizinho de outro enunciado (FOUCAULT, 2008, p. 31). Por fim, percebe-se o enunciado na sua descontinuidade, isto é, em um tempo ele produz um sentido e em outro produz outros.

O enunciado não é, pois:

\begin{abstract}
um elemento último, indecomponível, suscetível de ser isolado em si mesmo e capaz de entrar em jogo de relações com outros elementos semelhantes a ele; como um ponto sem superfície mas que pode ser demarcado em planos de repartição e em formas específicas de grupamentos; como um grão que aparece na superfície de um tecido de que é o elemento constituinte; como um átomo do discurso. (FOUCAULT, 2008, p.90).
\end{abstract}

Essas reflexões se mostram pertinentes para a avaliação dos sentidos da expressão “ativismo judicial”, pois conforme se observará, ele se articula com muitos outros acontecimentos os quais é necessário avaliar.

Um desses acontecimentos diz respeito ao fato de que não há um consenso acerca desse conceito ${ }^{1}$. Pontua-se que ativismo judicial é uma expressão importada dos Estados Unidos e inicialmente foi usada para demonstrar a atuação da Suprema Corte daquela nação durante os anos em que foi presidida por Earl Warren, entre 1954 e 1969. Durante tal composição houve uma grande mudança nas diversas práticas políticas. Assim, começava-se a construir uma jurisprudência progressista americana em matéria de direitos fundamentais (BARROSO, 2012). A par disso, o Poder Judiciário atuava sem que existisse qualquer ato do Congresso ou decreto presidencial que autorizasse um determinado tema.

1 Diversos autores discorrem sobre o tema (BAUM, 1987; CAPELLETTI, 1999; RAMOS, 2010; STRECK, 2012). Anota-se que o ativismo judicial norte-americano desenhou como objeto a contenção da atividade legislativa (WOLFE, 1991); já no Brasil, construiu-se não em conter excessos de outros Poderes, mas compensar a inação deles na implementação de direitos. Assim, traz-se a baila o momento da "desaposentação". 
O próprio criador da expressão judicial activism, o já mencionado historiador Arthur Schlesinger Jr., no seu texto famoso, deslanchou o enunciado ativismo não só no campo jurídico, mas também social e politico. Problema lançado, pois se criou imprecisão tanto terminológica do termo quanto a ser positivo ou negativo. Não menos conflitos interiores que o ativismo judicial acaba criando (KMIEC, 2004).

Assim, percebe-se que embora o enunciado ativismo judicial tenha sua emergência inicialmente em pátria norte-americana, os juristas daquele país ainda não entraram em acordo acerca dos limites ou probabilidades do seu sentido.

O enunciado "ativismo judicial", assim como todo enunciado, tem uma função de existência, a partir da qual se pode decidir se ele faz sentido ou não, de acordo com as regras que se sucedem ou se justapõem à sua forma de circulação.

Corroborando as formas de circulação dos sentidos de ativismo, Dworkin (2011), na sua percepção de ativismo judicial, tenta colocar a solução de problemas difíceis nos princípios, nas leis, no Direito, mas nunca na discricionariedade, ou seja, livre arbítrio do julgador. Mesmo sendo adepto do judicial review norte-americano autor, apresenta uma restrição ao ativismo judicial.

De outro mirante, Hart, negando a ideia de princípios de Dworkin, afirma que em casos difíceis (por exemplo, o caso de interrupção da gravidez de fetos anencéfalos) o juiz deve usar a discricionariedade, pois não há como prever uma resposta para todos os conflitos que apareçam. Acaba que, “em tais casos juridicamente não previstos ou não regulados, o juiz cria direito novo e aplica o direito estabelecido que não só confere, mas também restringe os seus poderes de criação do direito”. (HART, 2001, p. 335).

$\mathrm{Na}$ visão de Posner (2009, p. 423-424), o ativismo judicial não é visto como revolucionário, "mas um elemento para a concretização de direitos fundamentais enraizados na ideia de que ao decidir, o juiz tem o seu processo e, assim, pode fazer decisões discricionárias". Trata-se de um ativismo comprometido conscientemente ou não com as consequências da decisão.

Em contrapartida, mais uma vez Dworkin critica veemente o que ele intitula de "pragmatismo consequencialista utilitarista". Para o autor, um juiz ativista ignora toda uma cadeia de situações que não se ajustam à prática constitucional:

O ativismo é uma forma virulenta de pragmatismo jurídico. Um juiz ativista ignora o texto da constituição, a historia de sua promulgação, as decisões anteriores da Suprema Corte que buscaram interpreta-la e as duradoras tradições de nossa cultura politica. O ativismo ignora tudo isso para impor a outros poderes do Estado o seu próprio ponto de vista sobre o que a justiça exige. $\mathrm{O}$ direito como integridade condena o ativismo e qualquer pratica de jurisdição constitucional que lhe esteja 
próxima. Insiste em que os juízes apliquem a constituição por meio da interpretação, e não por fiat, querendo com isso dizer que suas decisões devam ajustar-se à pratica constitucional, e não ignora-la (DWORKIN, 2011, p. 272).

Ao contrario do pragmatismo, que adota critério prático de dotar este ou aquele princípio para ajudar a melhorar as coisas, Dworkin entende não estar dando ensejo ao ativismo judicial, "porque o seu protótipo de juiz não decide livremente, guiado pela própria consciência, e sim vinculado à prática constitucional de um País que adote a visão da direito como integridade (Estados Unidos, segundo Dworkin)" (RAMOS, 2010, p. 36).

No contexto brasileiro, Valle (2009, p. 19), refletindo sobre o termo ativismo, afirma que ele possui dois sentidos: finalístico e comportamental. Aquele indica o compromisso com a expansão dos direitos individuais, este, indica a visão pessoal de cada magistrado na interpretação da norma constitucional.

De outro lado, para Nery Junior e Abboud (2013, p. 528), “o ativismo é pernicioso para o Estado Democrático de Direito não podendo, portanto, diferenciar-se entre bom ou mau ativismo". Para os autores, a decisão ativista se pauta em convicções pessoais, senso de justiça do intérprete em desfavor da legalidade vigente. Ainda, para eles, o ativismo não possui ideologia ou orientação politica pré-definida:

\begin{abstract}
Pode ser extremamente liberal (análise puramente econômica do direito) ou de extrema esquerda (viés marxista). O que efetivamente caracteriza o ativismo é a substituição da legalidade vigente e do texto constitucional pelo senso de justiça e pelas conviç̧ões pessoais do magistrado da ocasião. (NERY JUNIOR; ABBOUD, 2013, p. 530).
\end{abstract}

Ainda na construção sobre o assunto no Brasil, Elival Ramos (2010) e Lênio Streck (2012) acolhem o ativismo judicial como um problema que pode ser remediado em vertentes diversas. Para Streck (2012) no enfrentamento da discricionariedade judicial, pois um ativismo judicial à brasileira gera uma serie de problemas ao constitucionalismo nacional levando, dentre outros, a perda de autonomia do direito pelos "predadores externos" do Direito que significa decisões judiciais pautadas em critérios não jurídicos. Elival Ramos (2010, p.25), por sua vez, falar em ativismo judicial é tocar no campo da legitimidade do controle de constitucionalidade, em suma "o que caberia discutir é se o modelo de Estado Constitucional de Direito escolhido pelo Constituinte seria mais adequado para implantar uma democracia".

Assim sendo, percebe-se que entre os autores, na construção do enunciado ativismo judicial, criou-se um documento construído a partir da experiência de receber a enunciação de outrem e sobre as tendências sociais estáveis que advém da apreensão ativa do discurso de outro que se manifestam nas formas da língua. 
Conforme aponta Foucault (2008), o enunciado nunca está só, sempre se relaciona com outros enunciados, podendo sempre tornar-se outro. Como uma função, um efeito enunciativo, o enunciado obedece a certas leis, que podem ser desde a ordem dos sujeitos que enunciam às instituições que o acolhem, de forma que o enunciado e os discursos nunca são livres. Nesse aspecto, portanto, nota-se que até entre os pesquisadores do assunto há uma disciplinamento e uma forma ordenada de produção de tais discursos. Percebe-se que eles delimitam um campo de verdade (ativismo judicial) onde o discurso deve se inserir, ou seja, as regras impostas para a construção de um discurso dentro de um campo do conhecimento.

Como se dá a construção do enunciado e, ainda, controla o domínio dos objetos, métodos, corpos de proposições verdadeiras ou falsas, um jogo de regras de definições, técnicas e instrumentos.

A par disso, colabora Foucault (1996, p.33-34):

\begin{abstract}
No interior dos seus limites, cada disciplina reconhece proposições verdadeiras e falsas; mas repele para o outro lado das suas margens toda uma teratologia do saber. O exterior de uma ciência está mais e menos povoado do que julgamos: certamente que há a experiência imediata, os temas imaginários que trazem e reconduzem incessantemente crenças sem memória; mas talvez não haja erros em sentido estrito, porque o erro não pode surgir e ser avaliado senão no interior de uma prática definida; em contrapartida, há monstros que circulam e cuja forma muda com a história do saber. Numa palavra, uma proposição tem de passar por complexas e pesadas exigências para poder pertencer ao conjunto de uma disciplina; antes de se poder dizê-la verdadeira ou falsa, ela deve estar, como diria Canguilhem, "no verdadeiro".
\end{abstract}

Assim, no próprio processo interno de construção do discurso ativista de uma maior e intensa participação do Judiciário na concretização dos valores e fins constitucionais, com ampla interferência no espaço de atuação dos outros dois Poderes (Legislativo e Executivo) existe um regramento e um constitutivo processo de classificação, ordenação e distribuição do que pode ser dito sobre o tema.

Em verdade, tais discursos não são construídos de forma aleatória. Eles não são neutros nem transparentes. Percebe-se que embora cada um traga suas restrições quanto aos limites de julgar, mas tanto em Hart como em Dworkin e demais expoentes no assunto, existe a ligação do desejo e do poder na construção do discurso ativista.

Enfim, o discurso, e no presente estudo, o discurso ativista, aparentemente, pode até nem ser nada, mas, os interditos que o atingem, revelam bem cedo e de imediato, o seu vínculo tanto ao poder quanto ao desejo. E isto não causa admiração. Porque, conforme Foucault (1996, p. 10), o discurso, demonstrado pela psicanálise, não é simplesmente aquilo que manifesta (ou esconde) o desejo. É, sobretudo, aquilo que é alvo de desejo. A própria historia, segundo o autor, sempre ensinou que "o discurso não é simplesmente aquilo que 
traduz as lutas ou os sistemas de dominação, mas é aquilo pelo qual e com o qual se luta, é o próprio poder de que procuramos assenhorear-nos".

Revela-se a seguir a conexão do discurso ativista com a construção jurisprudencial de um novo direito social: a desaposentação. Diante desse desdobramento se percebera as lutas dos Poderes (Legislativo, Executivo e Judiciário), Órgãos, doutrinadores e a própria opinião publica para se apossar do que pode ser dito sobre o enunciado ativismo judicial, o qual não é livre como ar que respiramos, mas que tem valor, que se apropria, que se repete, reproduz e transforma.

\section{ATIVISMO JUDICIAL E DESAPOSENTAÇÃO: perspectivas discursivas}

Roland Barthes (1977) chama atenção para a relação discurso e poder. Para o autor, o poder está presente nos mais finos mecanismos de intercâmbio social. Ele não só elenca o Estado, mas também, as classes, os grupos, as modas, as opiniões correntes, os espetáculos, os jogos, os esportes, as informações, as relações familiares e privadas, e até mesmo os impulsos liberadores que tentam de certa maneira contestá-lo.

O enunciado ativismo judicial é influenciado pelo poder como um objeto ideológico, que se insinua nos lugares onde não se ouve de início, nas instituições, nos ensinos, mas, no entanto, que ele, o poder, é sempre uno. Assim sendo, neste capítulo se verá as perspectivas discursivas do recente ativismo judicial, a desaposentação, nos diversos poderes, nas diferentes doutrinas e opinião pública.

\subsection{Os posicionamentos nos diversos poderes}

Diante da recente onda de reforma fiscal promovida pelo governo federal ${ }^{2}$, as regras para adquirir aposentadoria não ficaram de fora, pelo contrário, têm sido substrato para muita discursão para o parlamento brasileiro. Assim, antes mesmo desse novo arrocho fiscal, a desaposentação já era uma alternativa para aposentados que permaneciam no mercado de trabalho. Atual, como exemplo de ativismo judicial, percebe-se que há diversos posicionamentos sobre o assunto, com aplicação ampla e intensa pelo judiciário.

2 Já em 2012, se falava que a euforia dos bons resultados no Brasil corria o risco de perder o senso crítico e de esquecer que a boa gestão da economia exige análise permanente, antecipação dos gargalos e avaliação dos pontos nevrálgicos. Nem a Previdência Social ficou de fora de tal discurso, pois falar no fenômeno do envelhecimento progressivo das sociedades é tocar em medidas impopulares. (GIAMBIAGI; CASTELAR, 2012) 
E aqui, se faz útil analisar os diferentes discursos, assim, como os diferentes jogos polêmicos apresentados em torno da desaposentação.

Primeiramente deve-se saber o que é a desaposentação. Após, mostram-se os discursos de negação de órgão administrador do sistema previdenciário, e as instabilidades do poder legislativo sobre a referida vertente. Por derradeiro, vê-se o discurso do Poder Judiciário, sobretudo, o Superior Tribunal de Justiça, para concretizar aquele direito.

Ibrahim (2011, p. 701) ensina que a desaposentação é definida como a reversão da aposentadoria obtida no Regime Geral da Previdência Social ou mesmo em Regimes Próprios de Previdência de Servidores Públicos, "com o único objetivo de possibilitar a aquisição de um benefício mais vantajoso no mesmo ou em outro regime previdenciário". Assim, com o fim de obter novo benefício com melhores condições, em razão do novo tempo contributivo, surge a vontade da desaposentação.

No contexto atual, a desaposentação não possui previsão legal expressa, razão pela qual é negada pelos órgãos administrativos, os quais ainda argumentam pela violação do ato jurídico perfeito e do direito adquirido. Nesse sentido, o Instituto do Seguro Social-INSS não vem permitindo tal instituto, pois o Regulamento da Previdência Social (Decreto $n^{\circ}$. 3.048/99) não deu vazão para tal direito.

Para a Associação Nacional dos Auditores Fiscais do Brasil (ANFIP) a interferência entre os poderes, assim como, a composição de bancadas, pressão do governo, clientelismo e muitas outras situações formam o mecanismo que determina o temperamento do Congresso Nacional diante dos fatos e dos projetos que estão em pauta na chamada "Ordem do Dia",

\footnotetext{
Não adianta espernear: quem manda no Parlamento é quem tem poder. Evidentemente, a ingerência política do Executivo é um dado inevitável, que, no entanto, oscila conforme o índice de sucesso ou de popularidade do governo. Se o governo está forte, praticamente determina o resultado das votações de seu interesse. Se está fraco, tem que negociar e fazer muita pressão, valendo-se de recursos muitas vezes questionáveis e questionados. (ANFIP, 2014, p. 07)
}

Sobre esta visão do governo, é pertinente observar que diferentes poderes entram em cena, nesse processo. Assim, existe a ação do Estado que, por meio de alguns elementos, tais como, Governo, Administração, Exército, Polícia, Tribunais, Prisões e instituições como escola, igreja, família, Direito, política, sindicato, e ainda dispositivos culturais e informacionais, intervêm quer por forças repressoras, quer por ideias, a fim de submeter alguns segmentos sociais aos seus intentos. 
Mesmo assim, o instituto da desaposentação ou desaposentadoria realiza-se em mais de 7 mil ações que tramitam em várias instâncias do Poder Judiciário (ANFIP, 2013). Nada mais é que uma luta entre o INSS e segurados que buscam na justiça efetivação de direitos.

Em contrapartida, no dicionário do Ministério da Previdência Social a desaposentação é tida como um conceito que não existe. Para a Assessoria de Comunicação Social do INSS renunciar à aposentadoria não gera a desaposentação. "O ministro Garibaldi Alves não comenta matérias que estão tramitando na justiça, alega a assessoria a um pedido de entrevista com o ministro" (ANFIP, 2013, p. 13).

Para entender o que significa desaposentação para o Ministro do Poder Executivo, vale refletir, antes, sobre o que afirma Foucault acerca do funcionamento dos discursos em uma sociedade:

[...] suponho que em toda a sociedade a produção do discurso é simultaneamente controlada, selecionada, organizada e redistribuída por um certo número de procedimentos que têm por papel exorcizar-lhe os poderes e os perigos, refrear-lhe o acontecimento aleatório, disfarçar a sua pesada, temível materialidade (FOUCAULT, 1996, p.6-7).

Nas margens do discurso da desaposentação, instaura-se a preocupação do governo com o aumento das despesas da Previdência Social. Embora não existam estimativas do impacto financeiro da possível desoneração. Nota-se que é temerária a existência de sentenças favoráveis ao segurados e, com isso, cause um efeito cascata, estimulando novas demandas judiciais.

Segundo o trato dado pelo INSS, são mais de 500 mil os aposentados que retornaram ao mercado de trabalho com carteira assinada (ANFIP, 2013).

Posteriormente e com o surgimento de vários projetos de lei sobre o tema, o Poder Executivo, vendo a propagação divulgou pela primeira vez a despesa que será gerada para os cofres públicos caso o Supremo Tribunal Federal reconheça o direito à desaposentação, requerido hoje por milhares de ações em tramitação nos tribunais brasileiros. Segundo o governo, as ações podem provocar uma despesa de $\mathrm{R} \$ 70$ bilhões. $\mathrm{O}$ universo de aposentados beneficiados é estimado em 500 mil pessoas (CÂMARA DOS DEPUTADOS, 2014).

O referido número consta no anexo de riscos fiscais do projeto da LDO, Lei de Diretrizes Orçamentárias, que tramita na Comissão Mista de Orçamento. O texto enfatiza que o cálculo não é um reconhecimento do direto, mas uma projeção do risco potencial às contas públicas. Também não significa um provisionamento antecipado de recursos (CÂMARA DOS DEPUTADOS, 2014). 
A par disso, a negativa desse possível ativismo judicial ganha mais forca por meio do discurso do Governo sobre o déficit previdenciário.

Segundo dados de agosto de 2012, a arrecadação alcançou a cifra recorde de $\mathrm{R} \$ 22,5$ bilhões. Para o Poder Executivo, não se trata de grande feito, mas deu-se à formalização de empreendimentos e de trabalhadores. Em ano anterior, com a inclusão de aproximadamente quatro milhões de novos segurados ao sistema, o Anuário Estatístico da Previdência Social (AEPS), divulgou que a Previdência contava com 64,3 milhões de contribuintes. Entretanto, nem assim, afastou-se o discurso do déficit previdenciário (ANFIP, 2013, p. 19).

E mais, um rombo de $\mathrm{R} \$ 36$ bilhões nos cofres previdenciários foi o que foi declarado em 2012 pelo Ministério de Previdência e Assistência Social (MAPS). Em linhas gerais, fala-se na diferença entre o que é arrecadado e o que é pago em aposentadorias e em pensões, e em benefícios como auxílios acidente, doença e reclusão e os salários família e maternidade. Já em setembro de 2013, o Ministério informou que a arrecadação foi de R\$ 21,1 bilhões, e as despesas, de $\mathrm{R} \$ 26,1$. Um saldo negativo de $\mathrm{R} \$ 5$ bilhões (ANFIP, 2013, p $19)$.

Percebe-se que há um ciclo de continuidade pelo que foi dito sobre o déficit desde 2012. Para rompê-lo, é preciso renunciar a todos os temas que garantem o ciclo (FOUCAULT, 2008, p.28) e buscar a descontinuidade a partir dos enunciados, observando dois problemas principais: a relação entre acontecimento e discurso e relação entre enunciados (FOUCAULT, 2008, p.35).

É neste ponto de descontinuidade de discursos que se concentra a polêmica em torno das contas da Previdência. Muitos são os setores que tentam desconstruir tal discurso: acadêmicos, entidades de classe que municiam a sociedade e os legisladores com estudos sobre o tema sustentam que o déficit não existe. As mensagens lançadas pelos meios de comunicação, e mais, cada balanço anunciado pelo governo, deixam intranquilos os milhões de contribuintes, beneficiários do sistema (ANFIP, 2013, p. 19) e os que almejam a desaposentação não estão de fora.

Pensando com Foucault (2008, p.39-40), para que se fragilize esta cadeia discursiva, como almejam os setores acima, se deveriam findar os grupos de enunciados, determinandolhe o sistema de conceitos permanentes e coerentes que se encontram em funcionamento. Para isto, não se deve buscar coerência nos conceitos e sim o jogo dos seus aparecimentos e de sua dispersão. Enfim, não se pode buscar coerência nos enunciados, porque eles têm múltiplas relações . Em cada contexto aparecem de uma forma distinta. Não existe permanência, pois se 
deslocam, se dispersam constantemente. O que se percebe nas informações que constituem a recusa da desaposentação é que existe um emaranhado de jogos de sentidos envolvendo dados econômicos para se apaziguarem os ânimos daqueles que almejam mais uma dívida aos cofres públicos. Tudo indica que a desaposentação está dentro deste discurso.

Já no Poder Legislativo, com as pressões populares, existem diversos projetos de lei sobre a temática. No Senado Federal existe o PLS 91/20103 do senador Paulo Paim, do Rio Grande do Sul. Nota-se na justificativa do projeto de Lei, a necessidade da aprovação em virtude de seu deferimento por outros agentes:

(...) É sabido por todos de que o Egrégio Tribunal de Contas da União tem, reiteradamente, proclamado o direito de o funcionário público renunciar à aposentadoria já concedida para obter outra mais proveitosa em cargo público diverso.

Igualmente, o Poder Judiciário tem reconhecido esse direito em relação à aposentadoria previdenciária, contudo, o Instituto Nacional de Seguridade Social insiste em indeferir essa pretensão, compelindo os interessados a recorrerem à Justiça para obter o reconhecimento do direito (...). (SENADO FEDERAL, 2014)

Em contrapartida, na Câmara dos Deputados existem sete projetos autorizando a desaposentação ${ }^{4}$. A Comissão de Seguridade Social da Câmara aprovou projeto de lei (PL 3.884/08) do deputado Cleber Verde, contudo, na justificativa do projeto, a aprovação pelo Judiciário ainda marca a principal premissa para a criação de tal direito ${ }^{5}$ :

\begin{abstract}
Igualmente, o Poder Judiciário tem reconhecido esse direito em relação à aposentadoria previdenciária, contudo, o Instituto Nacional do Seguro Social, insiste em rejeitar essa pretensão, compelindo os interessados a recorrerem à Justiça para obter o reconhecimento desse direito.

Entendimento recente manifestado pela egrégia QUINTA TURMA do Colendo Superior Tribunal de Justiça, por unanimidade, onde a condutora do acórdão foi a Exma. Sra. Ministra Dra. LAURITA VA publicado no DJ EM 26-SET-2005, P. 433, citando outros acórdãos no voto proferido pelo Exmo. Sr. Ministro dr. HÉLIO QUAGLIA BARBOSA, também da SEXTA TURMA e o voto prolatado pelo Exmo. Sr. Ministro Dr. JOSÉ ARNALDO DA FONSECA, da Egrégia QUINTA TURMA, do C. STJ, favoravelmente a ao que propomos(...). (CÂMARA DOS DEPUTADOS, 2013)
\end{abstract}

Contudo, naquela própria casa existem dissidentes sobre o assunto. Votou contra o projeto o deputado Amauri Teixeira, do PT da Bahia:

O sistema de desaposentação perturba o sistema, tira a base atuarial. O sistema de desaposentação também pode levar contribuintes para outros regimes sem haver

3 O PLS 91/2010 encontra-se desde janeiro de 2014 na Subseção de Coordenação Legislativa do Senado. Conjuntamente com ele, tramitam nove outros Projetos de Lei do Senado e um da Câmara dos Deputados acrescentando assuntos ao tema desaposentação. A íntegra de todo o PLS 91/2010 encontra-se no site do Senado Federal. (SENADO FEDERAL, 2010)

4 De acordo com o site da Câmara dos Deputados, cada projeto tem suas peculiaridades, mas todos autorizam a desaposentação e já incluem, até mesmo a despensão. (CÂ̂MARA DOS DEPUTADOS, 2013)

5 Atualmente, o PL 3.884/08 encontra-se apensado ao PL 2682/2007, também do mesmo autor, aguardando apreciação conclusiva pelas Comissões. (CÂMARA DOS DEPUTADOS, 2013) 
compensação entre eles, desfalcando o equilíbrio atuarial. (CÂMARA DOS DEPUTADOS, 2013)

Em oposição, o deputado do André Zacharow (PMDB-PR) é relator de PL 2567/11 sustenta que,

A desaposentação é uma "questão de bom senso". "Quem já trabalhou durante a vida toda e depois continuou na ativa, mesmo aposentado, é obrigado a contribuir com a Previdência. Se ele fosse isento de pagamento, tudo bem, mas como é obrigado a recolher, então essa parcela deve ser acrescida ao cálculo da sua aposentadoria posterior". (CAMARA DOS DEPUTADOS, 2014)

Percebe-se pelo próprio jogo de palavras e frases escolhido pelos deputados apresentam propriedades singulares e papeis preestabelecidos. As palavras "perturba" e “desfalcando" escolhidas pelo deputado Amauri Teixeira conferem um sentido pejorativo ao instituto enquanto a frase "questão de bom senso" sugere o acolhimento da ideia por todos em geral.

A desaposentação é instrumento que vem se tornando conhecido pela população. Não apenas pela comunidade jurídica, mas observa-se gradativa divulgação disseminada pelas mídias. Por meio desse mecanismo, o aposentado que retornou ao mercado de trabalho renuncia ao benefício pago pelo INSS e pede o recálculo da aposentadoria, incorporando as contribuições e o tempo de serviço acumulados com o novo trabalho. O objetivo é conseguir uma aposentadoria maior.

No Poder Judiciário, após avalanche de pedidos de desaposentação a jurisprudência, de modo geral, acolheu o instituto e seus fundamentos em todos os tribunais regionais federais (AC 200561040082099, Juiz Sergio Nascimento, TRF 3- Decima Turma, 27.01.2010 e AC 200971000172414, Eduardo Vandré Oliveira Lema Garcia, TRF 4- Sexta Turma, 05.02.2010), sendo que a matéria esta pacificada no Superior Tribunal de Justiça. O Supremo Tribunal Federal reconheceu repercussão geral sobre o tema, através do RE 381.367, o qual esta pendente de julgamento.

Contudo, a disseminação do discurso da desaposentação deu-se no tribunal de cúpula federal: o Superior Tribunal de Justiça. Isto porque pacificou o assunto ao afirmar que não houve declaração de inconstitucionalidade do art. 18 da Lei 8.213/91, ao contrario, deu-se ao dispositivo interpretação diversa da pretendida pelo INSS. O referido Tribunal, no jogo do diálogo, por meio de um ritual sobre o que pode ser dito sobre a desaposentação deferiu o direito: a aposentadoria é tratada como direito disponível, por isso, sujeito a renúncia. Com a decisão, o segurado poderá reaproveitar o tempo de contribuição para fins de concessão de novo benefício no mesmo regime ou em outro previdenciário. Concluiu que não precisava 
haver a devolução dos proventos já recebidos, devido à natureza alimentar da aposentadoria. (SUPERIOR TRIBUNAL DE JUSTIÇA, 2013)

Na visão jurisprudencial, fica evidente que a desaposentação está dentro de um sistema complexo de restrição, indicando que lugar deve ocupar e qual o alcance do seu significado. Percebe-se que o Superior Tribunal de Justiça define um ritual já definindo a extensão do direito, enfim, todo o conjunto de sinais que devem acompanhar o discurso. Esclarecendo mais, ensina Foucault:

\begin{abstract}
A forma mais superficial e mais visível destes sistemas de restrição é constituída por aquilo que se pode agrupar sob o nome de ritual; o ritual define a qualificação que devem possuir os indivíduos que falam (e que, no jogo do diálogo, na interrogação, na recitação, devem ocupar determinada posição e formular determinado tipo de enunciados); define os gestos, os comportamentos, as circunstâncias e todo o conjunto de sinais que devem acompanhar o discurso; o ritual fixa, por fim, a eficácia, suposta ou imposta, das palavras, o seu efeito sobre aqueles a quem elas se dirigem, os limites do seu valor constrangedor. Os discursos religiosos, jurídicos, terapêuticos, e em parte também os políticos, não são dissociáveis desse exercício de um ritual que determina para os sujeitos falantes, ao mesmo tempo, propriedades singulares e papéis convenientes. (FOUCAULT, 1996, p. 38-39).
\end{abstract}

Para Mauro Cappelletti, o problema não está em prevenir que os juízes sejam criadores do direito e como tais se apresentam, "mas que seja pervertida a característica formal essencial, isto é, o 'modo' do processo jurisdicional”. Continua afirmando que as vantagens de tal ficção são intensamente superadas pelas desvantagens, principalmente nas sociedades democráticas "nas quais o processo legislativo torna-se particularmente lento, obstruído e pesado, forcando por consequência o aumento do grau de criatividade da função judiciária”. (1999, p. 131-132)

Hoje em dia, é muito comum as diversas hipóteses de controvérsias judiciárias sobre problemas de elevada importância social, as quais são tão expostas ao severo juízo crítico da coletividade. Com isto, ressalta Cappelletti, que tais decisões não podem ser resolvidas com mediante "sutis exercícios de semântica ou hábeis jogos de especulação abstrata." Em verdade, tanto para o homem do povo quanto para o experto as escolhas do juiz tornam-se evidentes. Assim, para impedir a subjetividade dos juízes, "essas escolhas não devem ser ocultadas por meio de contorções logicas e verbais, tornando-se assim mais responsáveis e também mais democráticas". Contribui o autor, que diante da criação da função judiciaria, devem ser patentes as reais razões de qualquer escolha e revelados os conflitos entre as varias soluções possíveis, levando-se a tona, também, os elementos de incerteza, "abrindo-se o caminho, se for o caso, para intervenções reparadoras do legislador”. (1999, p. 132).

É bem verdade que a criação jurisprudencial é a forma de produção do direito em que podem ter interesse muitas pessoas, e não apenas as partes do caso concreto. Para Mauro 
Cappelletti, o direito criado pelos juízes tem por base uma 'audiência' ('hearing') incompleta dos interesses envolvidos. Para o autor, a criação jurisprudencial do direito é lenta, gradual e experimental. "Outros sujeitos interessados, senão ouvidos hoje podem sê-lo amanhã; e um juiz sensível será capaz de corrigir, melhorar e modelar um 'direito' que nunca se mostra inteira e definitivamente "feito"' (CAPPELLETTI, 1999, p. 104-105).

Ressalta, ainda, que embora a profissão ou carreira dos juízes possa ter um ar de isolamento da sociedade da vida social, a sua função constrange, dia após dia, a se inclinar sobre essa realidade, pois são chamados a decidir casos envolvendo pessoas reais, problemas atuais da vida, enfim, fatos concretos. "Neste sentido, a produção judiciaria do direito tem a potencialidade de ser altamente democrática, vizinha e sensível as necessidades da população e às aspirações sociais." Contudo, ressalta o autor, que deve haver certas condições para que isto se torne realidade. (CAPPELLETTI, 1999, p. 105)

Em verdade, o Superior Tribunal de Justiça, em sua construção jurisprudencial, produziu uma vontade de verdade apoiada sobre um suporte e distribuição institucional que tende a exercer um poder de coerção, uma espécie de pressão sobre os outros discursos contrários ao seu. Nesse sentido, auxilia Foucault:

E creio que esta vontade de verdade, por fim, apoiando-se numa base e numa distribuição institucionais, tende a exercer sobre os outros discursos - continuo a falar da nossa sociedade - uma espécie de pressão e um certo poder de constrangimento. Estou a pensar na maneira como a literatura ocidental teve de apoiar-se, há séculos a esta parte, no natural, no verosímil, na sinceridade, e também na ciência — numa palavra, no discurso verdadeiro (FOUCAULT, 1996, p. 17-18).

Por todo o exposto, observa-se que não somente o Poder Judiciário faz seu papel de limitar e recortar o discurso sobre a desaposentação. Existe espaço limitador para o tema também pelo Poder Executivo e Legislativo que irão escolher o que escrever ou não sobre o assunto e quais campos de verdade ele deverá ser inserido. Assim, pode-se perceber que em tal discurso, há quem o exclua, o limite e quem se aproprie dele.

Enfim, nos interstícios do discurso da desaposentação, como exemplo de ativismo judicial, existem formas para sua construção como um jogo de regras e definições, de técnicas e instrumentos necessários para sua aceitação como verdadeiro.

\subsection{Nas diferentes doutrinas}

Adentrando no discurso do ativismo judicial e seus atravessamentos, Bork (2003, p. 9) indica que "é mais fácil saber um voto ou uma decisão pelo nome do juiz do que pela tese jurídica aplicável ao caso concreto". A referida visão, tida por alguns como cética 
(FRIEDMAN, 2005), pode acarretar duas consequências negativas: acaba por deslegitimar a função judicial e libera os juízes para fazerem o que quiserem (DORF, 2006).

Para Luis Roberto Barroso (2012), existem duas razões que se opõem a tal perspectiva. Na primeira, de cunho subjetivista, os juízes são verdadeiramente vocacionados e apresentam como motivação primária e primordial a interpretação adequada do direito vigente, com a valoração imparcial dos elementos fáticos e jurídicos relevantes. Já a perspectiva objetivista mostra que leis, Constituição, jurisprudência serão limitadores nas práticas jurídicas.

Para o realismo jurídico, teoria criada no século XX e que abre espaço ao ativismo judicial, o formalismo jurídico já não atendia mais aos anseios sociais. Findou-se a ideia de que a atividade judicial seria mecânica, acrítica e unívoca (GARCIA NETO, [200-]).

Enfatizando que o direito tem ambiguidades e contradições, o realismo jurídico sustentava que a lei não é o único - e, em muitos casos, sequer o mais importante - fator a influenciar uma decisão judicial. Em grandes possibilidades, é o juiz que faz a escolha do resultado, à luz de suas intuições, personalidade, preferências e preconceitos.

Nos Estados Unidos, por exemplo, sustentava-se o discurso de que as decisões judiciais não passam de escolhas políticas, encobertas por um discurso que procura exibir neutralidade (KENNEDY, 1982).

Assim como na América Latina ${ }^{6}$, no Brasil, o Poder Judiciário tem sido conduzido a decidir sobre questões no campo da genética, da cibernética, ambientais, evolução científica e técnica e efetivação de direitos sociais. Para Streck e Saldanha (2013, p. 403), essa atuação do judiciário deve ser entendida a partir do modelo de Estado brasileiro, ou seja, "de regime presidencialista, conformado pelos poderes executivo, legislativo e judiciário em que o tribunal máximo faz parte deste último e não se encontra como entidade separada e autônoma, como ocorre em alguns sistemas europeus".

Entretanto, comparando-se com os Estados Unidos, aqui no Brasil, o peso político é menos relevante ou, no mínimo, menos visível, pois a maior parte dos cargos no Judiciário é preenchida mediante concurso público e promoções internas ${ }^{7}$. Mas não é este o caso das nomeações para o Superior Tribunal de Justiça, por exemplo, em que os parâmetros constitucionais são vagos (reputação ilibada e notável saber jurídico).

6 Na Argentina, por exemplo, a Corte Suprema da Justiça daquele país decidiu ser crime federal espionar o Facebook de outra pessoa. (SUPREMO TRIBUNAL FEDERAL, 2014)

7 Cf. o artigo 93 da $\mathrm{CF} / 88$. 
Em contrapartida, na concretização de direitos fundamentais nos Estados Unidos tem sido enfatizada a extrema importância do gênero e da raça na determinação de certos padrões decisórios do juiz. Já no Brasil, em tribunais superiores e no Superior Tribunal de Justiça a origem profissional do Ministro submete características perceptíveis no seu modo de atuação judicial: Ministros que vêm da Magistratura, do Ministério Público, da advocacia privada, da advocacia pública ou da academia tendem a colocar, no exercício da jurisdição diária, a influência de experiências enquanto atuante na antiga carreira (SILVA, 2008).

Percebe-se que as decisões judiciais são influenciadas por diversos fatores. Na doutrina de Fábio Comparato (2004, p. 153), “os Tribunais não são guardiães de um direito que não sofre o influxo da realidade, das maiorias políticas e dos múltiplos atores de uma sociedade plural".

Explica-nos Cambi (2009, p.245) que no contexto atual, os diversos órgãos, entidades e, sobretudo, as pessoas se agitam, atuando e reagindo na perspectiva de alcançar direitos. É possível notar os Poderes Legislativo e Executivo, o Ministério Público, os Estados da Federação, assim como entidades da sociedade civil almejam eles, nos autos ou fora deles, fazer valer seus direitos, interesses e, também, preferências. Concretizam suas atuações por meios formais e informais. E o Superior Tribunal de Justiça, como ocorre com as cortes constitucionais, não vive fora do contexto político-institucional sobre o qual sua atuação repercute.

Assim, constrói-se uma atuação judicial peculiar, na qual a jurisprudência diz o que pode se entender por direito. É a expressão deste pensamento, o Ministro Humberto Gomes de Barros do Superior Tribunal de Justiça:

\footnotetext{
Não me importa o que pensam os doutrinadores. Enquanto for Ministro do STJ, assumo autoridade da minha jurisdição. O pensamento daqueles que não são Ministros deste Tribunal importa como orientação. A eles, porem, não me submeto (...). Esse é o pensamento do STJ, e a doutrina que se amolde a ele. É fundamental expressarmos o que somos. Ninguém nos dá lições. Não somos aprendizes de ninguém. Quando viemos para este tribunal, corajosamente assumimos a declaração de que temos notável saber jurídico - uma imposição da Constituição Federal. Pode não ser verdade. Em relação a mim, certamente, não é, mas, para efeitos constitucionais, minha investidura obriga-me a pensar que assim seja. (SUPERIOR TRIBUNAL DE JUSTICA, 2003)
}

Realçando a interferência de fatores no momento de julgar, tais como o próprio poder, corrobora a doutrina de Luís Roberto Barroso:

Diante disso, o papel e as motivações da Corte sofrem a influência de fatores como, por exemplo: a preservação e, por vezes, a expansão de seu próprio poder; a interação com outros Poderes, instituições ou entes estatais; e as consequências práticas de seus julgados, inclusive e notadamente, a perspectiva de seu efetivo cumprimento. (BARROSO, 2011, p.110). 
Note-se, todavia, em desfecho do tópico, que eventuais preferências políticas do juiz são contidas não apenas por sua subordinação aos sentidos mínimos das normas constitucionais e legais, como também por fatores extrajudiciais, dentre os quais se podem destacar: a interação com outros atores políticos e institucionais, a perspectiva de cumprimento efetivo da decisão, as circunstâncias internas dos órgãos colegiados, além da opinião pública. Assim, percebe-se que os discursos dos juízes não são ininterruptos, mas são descontínuos em vista dos procedimentos de controle inerentes a toda produção discursiva.

Nesse sentido, enfatiza Foucault (1996, p. 52-53) que os discursos são práticas descontínuas, que se cruzam em algumas vezes, mas também se ignoram ou excluem:

Um princípio de descontinuidade: que haja sistemas de rarefacção não quer dizer que aquém deles, ou para-além deles, reine um grande discurso ilimitado, contínuo e silencioso, discurso que, por via desses sistemas, se encontraria reprimido ou recalcado, e que teríamos de reerguer, restituindo-lhe a palavra. Não é necessário imaginar um não dito ou um impensado que percorre e entrelaça o mundo com todas as suas formas e todos os seus acontecimentos, o qual teríamos de articular, ou, finalmente, pensar. Os discursos devem ser tratados como práticas descontínuas que se cruzam, que às vezes se justapõem, mas que também se ignoram ou se excluem.

No que se refere à desaposentação, a própria doutrina que tem uma certa “autorização" para falar sobre o instituto (MARTINEZ, 2008; IBRAHIM, 2007; COELHO, 1999; CASTRO; LAZARRI, 2006) não a classifica como ativismo judicial, mas ao conceituála definem o tipo de positividade sobre o discurso. Ou melhor, tais doutrinadores, na visão de Foucault (1996, p. 148) 'falavam da 'mesma coisa', colocando-se no 'mesmo nível' ou a 'mesma distância', desenvolvendo 'o mesmo campo conceitual', opondo-se sobre 'o mesmo campo de batalha'". Observa-se nos conceitos o jogo das influências que pôde ser exercido de um autor a outro:

[...] desaposentação e uma renuncia a aposentação, sem prejuízo do tempo de serviço ou do tempo de contribuição, por ser irrenunciáveis, seguida ou não de volta ao trabalho, restituindo-se o que for atuarialmente necessário para a manutenção do equilíbrio financeiro dos regimes envolvidos com o aproveitamento do período anterior no mesmo ou em outro regime de previdência social, sempre que a situação do segurado melhorar e isso não causar prejuízo a terceiro. (MARTINEZ, p. 36, 2008)

(...) traduz-se na possibilidade do segurado renunciar a aposentadoria com o proposito de obter beneficio mais vantajoso, no regime geral de previdência social ou em regime próprio de previdência, mediante a utilização de seu tempo de contribuição. O presente instituto e utilizado colimando a melhoria do status financeiro do aposentado (IBRAHIM, p. 35, 2007)

A contagem do tempo de serviço vinculado a antiga aposentadoria para fins de averbação em outra atividade profissional ou mesmo, para dar suporte a uma nova e mais benéfica jubilação. (COELHO, p. 1130-1134, 1999)

(...) é o direito do segurado ao retorno a atividade remunerada, com o desfazimento da aposentadoria por vontade do titular, para fins de aproveitamento do tempo de 
filiação em contagem para nova aposentadoria, no mesmo ou em outro regime previdenciário (CASTRO; LAZARRI, p. 509, 2006)

Essas diferentes obras em livros diversos simbolizam uma massa de textos que criam uma mesma formação discursiva. Bork, Friedman, Dorf, Barroso, Kennedy, Streck, Saldanha, Cambi, Comparato, Silva e tantos autores que se conhecem e se ignoram, se criticam, se plagiam e invalidam uns aos outros, se reencontram sem saber e entrecruzam obstinadamente seus discursos singulares numa espécie de trama os quais não dominam e que o todo não percebem acabam criando uma positividade do discurso sobre o ativismo judicial.

Percebe-se que essas figuras e individualidades diversas não se comunicam somente por uma espécie de encadeamento lógico das proposições que eles apresentam, assim como, pela recorrência dos temas e pela pertinácia de uma significação transmitida, esquecida, redescoberta, mas se comunicam pela forma de positividade de seus discursos. Enfim, uma "forma de positividade (e as condições de exercício da função enunciativa) define um campo em que, eventualmente, podem ser desenvolvidos identidades formais, continuidades temáticas, translações de conceitos, jogos polêmicos”. (FOUCAULT, p.144, 2008)

Além dessas práticas descontínuas que se cruzam, justapõem-se ou ora se ignoram, ora se excluem, os discursos sobre o que seja ativismo judicial para os doutrinadores, "liga os indivíduos a certos tipos de enunciação e lhes proíbe, consequentemente, todos ou outros" (FOUCAULT, 1996, p.42-43). Para que uma doutrina sobre determinado enunciado exista é necessário o reconhecimento das mesmas verdades e a aceitação de certa regra, mais ou menos flexível, em conformidade com os discursos validados. Logo, os doutrinadores do ativismo judicial se servem de certos tipos de enunciação para ligar indivíduos entre si, e desse modo os diferenciar de todos os outros.

\subsection{A opinião pública}

De acordo com os ensinamentos de Barroso (2002, p. 69), “o poder dos tribunais e juízes, assim como todo poder político em um Estado democrático, é representativo". Ou seja, é executado em nome do povo e deve prestar contas à sociedade. Em verdade, concepção óbvia, do ponto de vista da teoria democrática, a realidade é que a percepção concreta desse fenômeno é um tanto recente. O cidadão comum, à opinião pública e aos meios de comunicação não afetava diretamente o Judiciário e era tido como virtude.

Hoje, o quadro é outro. A legitimidade democrática do Judiciário, ao interpretar a Constituição, liga-se à sua capacidade de corresponder ao sentimento social. E isto pode ser 
visto em casos como desaposentação, casamento homoafetivo, interrupção de gestação e demarcação de terras indígenas.

A autoridade para fazer valer a Constituição, como qualquer autoridade que não repouse na força, depende da confiança dos cidadãos. Se os tribunais interpretarem a Constituição em termos que divirjam significativamente do sentimento social, a sociedade encontrará mecanismos de transmitir suas objeções e, no limite, resistirá ao cumprimento da decisão (POSTO; SIEGEL, 2007, p. 373).

A relação entre órgãos judiciais e a opinião pública envolve muitas complexidades e sutilezas demasiadas. De um lado, a atuação dos tribunais, em geral, no controle de constitucionalidade das leis, em particular, é vista, como um mecanismo relevante de contenção das paixões passageiras da vontade popular. Na outra parte, a ingerência do Judiciário, em linha oposta à das maiorias políticas, enfrenta, desde muito tempo, questionamentos quanto à sua legitimidade democrática. Nesse ambiente criado, é possível estabelecer uma correlação entre Judiciário e opinião pública e afirmar que, quando haja desencontro de posições, a tendência é no sentido de o Judiciário se alinhar ao sentimento social (SADEK, 2009, p.714).

A desaposentação, como outros temas, ${ }^{8}$ pode representar, no Brasil, demandas que correspondem ao anseio da sociedade. No constitucionalismo democrático, o exercício do poder envolve a interação entre as cortes judiciais e o sentimento social, manifestado por via da opinião pública ou das instâncias representativas. A participação e o engajamento popular influenciam e legitimam as decisões judiciais. Entretanto, para Luís Roberto Barroso a opinião pública deve ser tratada com ressalvas:

O mérito de uma decisão judicial não deve ser aferido em pesquisa de opinião pública. Mas isso não diminui a importância de o Judiciário, no conjunto de sua atuação, ser compreendido, respeitado e acatado pela população. A opinião pública é um fator extrajurídico relevante no processo de tomada de decisões por juízes e tribunais. Mas não é o único e, mais que isso, nem sempre é singela a tarefa de captá-la com fidelidade. (BARROSO, 2011, p. 119).

A par disso, observa-se que há uma preocupação pelo discurso do jurista quanto à interferência da opinião pública nas práticas jurídicas. Em contrapartida, percebe-se a apropriação social dos discursos, numa escala muito maior. E a educação, elenca Foucault (1996), é responsável por esta apreensão social sobre determinados discursos. Nota-se que cada vez mais o acesso à educação faz com que as pessoas conheçam determinados assuntos e

8 Três exemplos de decisões do Supremo Tribunal Federal que indicaram mudança de entendimento que hoje representa demandas sociais: a limitação das hipóteses de foro por prerrogativa de função (cancelamento da 
se apropriem dele. Assim, geralmente, pessoas que buscam a desaposentação, ou mesmo o servidor público que busca direito de greve já são dotadas de um grau de escolaridade e com tal conhecimento, é possível manter ou modificar apropriação de discursos:

A educação pode muito bem ser, de direito, o instrumento graças ao qual todo o indivíduo, numa sociedade como a nossa, pode ter acesso a qualquer tipo de discurso; sabemos no entanto que, na sua distribuição, naquilo que permite e naquilo que impede, ela segue as linhas que são marcadas pelas distâncias, pelas oposições e pelas lutas sociais. Todo o sistema de educação é uma maneira política de manter ou de modificar a apropriação dos discursos, com os saberes e os poderes que estes trazem consigo. (FOUCAULT, 1996, p. 43)

Entretanto, não é qualquer discurso da opinião pública sobre o ativismo judicial que deve ser encarado como verdadeiro. Seguindo a linha de Foucault (2008, p.56), pode-se deduzir que o discurso de preocupação pelo que é construído pela opinião publica só ganhará corpo a partir de quem o produz, quem fala, quem é o seu titular. E mais, o lugar de produção é fundamental para saber se aquele discurso apresenta presunção de verdadeiro:

Primeira questão: quem fala? Quem, no conjunto de todos os sujeitos falantes, tem boas razões para ter esta espécie de linguagem? Quem é seu titular? Quem recebe dela sua singularidade, seus encantos, e de quem, em troca, recebe se não sua garantia, pelo menos a presunção de que é verdadeira? Qual é o status dos indivíduos que têm - e apenas eles - o direito regulamentar ou tradicional, juridicamente definido ou espontaneamente aceito, de proferir semelhante discurso?

O discurso nada mais é do que o reflexo de uma verdade que está sempre a nascer diante dos olhos; assim, a opinião pública sobre as práticas jurídicas acaba sendo um poder soberano e direto; um olho que observa; um dedo que toca; órgão que decifra sinais. Isto porque todo um feixe de relações de poder e sentido se encontra em jogo. Mais uma vez Focault (1996, p. 49-50) auxilia na avaliação dos jogos estratégicos em questão:

Aparentemente, que civilização respeitou mais o discurso do que a nossa? Onde é que mais e melhor se honrou o discurso? Onde é que, ao que parece, mais radicalmente se libertou o discurso dos seus constrangimentos e se universalizou? Ora, parece-me que sob esta aparente veneração do discurso, sob esta aparente logofilia, esconde-se uma espécie de temor. Tudo se passa como se os interditos, as barragens, as entradas e os limites do discurso tivessem sido dispostos de maneira a que, ao menos em parte, a grande proliferação do discurso seja dominada, de maneira a que a sua riqueza seja alijada da sua parte mais perigosa e que a sua desordem seja organizada segundo figuras que esquivam aquilo que é mais incontrolável; tudo se passa como se se tivesse mesmo querido apagar as marcas da sua irrupção nos jogos do pensamento e da língua.

\section{E continua o filósofo:}

Há sem dúvida na nossa sociedade, e imagino que em todas as outras, com base em perfis e decomposições diferentes, uma profunda logofobia, uma espécie de temor surdo por esses acontecimentos, por essa massa de coisas ditas, pelo surgimento de todos esses enunciados, por tudo o que neles pode haver de violento, de descontínuo,

Súmula $n^{\circ} 394$ ); a proibição do nepotismo, conduta que por longo tempo foi tido como social e juridicamente aceita; e a fidelidade partidária, penalizando o "troca-troca" de partidos após as eleições. 
de batalhador, de desordem também e de perigoso, por esse burburinho incessante e desordenado do discurso.

Todo lugar "próprio" é alterado por aquilo que, dos outros, já se acha nele, afirma Michel de Certeau (1998, p. 110). Para o autor, o criador de um discurso ao esquecer o trabalho coletivo no qual se inscreve ao isolar de sua gênese histórica o objeto de seu discurso, acaba praticando a denegação de sua situação real. Essa separação do "autor de discurso" do "coletivo" cria a ficção de um lugar próprio. E isto apaga os traços no qual pertence uma pesquisa e camufla as condições de produção do discurso e de seu objeto.

Assim sendo, não há como negar que as "influencias" da opinião pública sobre o ativismo judicial aparecem num texto, ou mesmo numa definição de pesquisa, pelos efeitos de alteração e elaboração que ali produziram. Intercâmbios, leituras e confrontos que formam as suas condições de possibilidade, "cada estudo particular é um espelho de cem faces (neste espaço os outros estão sempre aparecendo), mas um espelho partido e anamórfico (os outros aí se fragmentam e se alteram)".

\section{CONCLUSÕES}

Em toda sociedade, a produção de discursos é controlada, com o fim de retirar os possíveis poderes e os imensos perigos que tal discurso pode desenvolver. Além de conter acontecimentos aleatórios que podem surgir nessa produção e também causar desordem.

Na maioria das vezes estão ligados uns aos outros e são como grandes edifícios que asseguram a distribuição dos sujeitos falantes nos diferentes tipos de discurso e asseguram a apropriação dos discursos a certas categorias de sujeitos. Numa palavra, são os grandes procedimentos de sujeição do discurso.

E não se pode enganar: até mesmo na ordem do discurso verdadeiro, ainda os citados pelos órgãos oficiais, mesmo na ordem do discurso publicado e liberto aparentemente de todo o ritual (como os discursos orais cotidianos), exercem-se ainda formas de apropriação do segredo e de não intermutabilidade do discurso. São dados divulgados que por jogos estratégicos do pensamento e da língua acabam sendo repressores.

Sabe-se que não há o direito de dizer o que se apetece, que não há o direito de falar de tudo em qualquer circunstância, que quem quer que seja, enfim, não pode falar do que quer que seja sem se submeter a um controle.

O discurso não é simplesmente aquilo que traduz as lutas ou os sistemas de dominação, mas é, sobretudo, aquilo pelo qual e com o qual se luta, é o próprio poder de que se procura assenhorar, conforme disse Foucault. Assim sendo, embora existam as contenções 
do Poder Executivo ou mesmo a ineficiência do Poder Legislativo, o discurso ativista produzido pelos Tribunais brasileiros, sobretudo, o Superior Tribunal de Justiça tende também a ser um mecanismo de controle. Com um argumento de que o ativismo judicial surgiu como forma de resolução de problemas da sociedade, diante de uma violação arbitrária, por parte do legislador, dos direitos fundamentais garantidos pela Constituição Federal, e contribuir para a real efetivação de um Estado Democrático de Direito, mesmo assim, existem também diversos atravessamentos.

Tratado como neologismo jurídico para designar o ato de desconstituição do beneficio, representando renuncia às mensalidades antes mantidas e uma nova aposentação ou não, a desaposentação é uma criação doutrinária dentre vários temas controvertidos do Direito Previdenciário brasileiro. Também não foge de toda a massa de textos que pertencem a uma mesma formação discursiva, a qual não é solta.

Fruto de discurso ou não, a insatisfação dos aposentados com o valor de seus proventos, notadamente os reajustes anuais, pode ser visto como fator que tem motivado o retorno ao trabalho de muitos deles para complementação da renda mensal. Ao voltarem para suas atividades laborativas, tornam-se novamente segurados obrigatórios do regime geral e sujeitos passivos do tributo da contribuição previdenciária.

Partindo-se do senso comum, entendem que seria justo receber uma contraprestação pelo pagamento da contribuição previdenciária, motivo pelo qual postulam a desaposentação como revisão do valor do beneficio. Mesmo nesse discurso há uma grelha complexa que poderá se modificar tanto com a criação da lei sobre o instituto ou com a palavra final do Supremo Tribunal Federal.

Como todo discurso, o discurso ativista não é livre. Está longe de ser transparente e neutro. Existe uma cadeia de situações que os controlam e os selecionam. A doutrina, o posicionamento do Poder Executivo e Legislativo e a opinião publica acabam por controlar mesmo que indiretamente as decisões ativistas do Poder Judiciário. Embora seja um discurso de aparente veneração quanto a efetividade de direitos, em suas margens extirpa-se tudo que há nele de violento, de descontinuo e desordenador. 


\section{REFERÊNCIAS}

ASSOCIAÇÃO NACIONAL DOS AUDITORES FISCAIS DO BRASIL-ANFIP.

Seguridade Social e Tributação. Brasília, ano XXII, nº 114, janeiro/maio, 2013.

. Seguridade e Tributação. Brasília, ano XXIII, n. 114, abril/junho, 2013.

Seguridade e Tributação. Brasília, ano XXIII, n. 118, abril/junho, 2014.

\section{BARROSO, Luís Roberto. Curso de Direito Constitucional Contemporâneo: Os conceitos}

fundamentais e a construção do novo modelo. 3 ed. São Paulo: Saraiva, 2012.

- A segurança jurídica na era da velocidade e do pragmatismo. In: Temas de direito constitucional, tomo I, 2002.

.Constituição, democracia e supremacia judicial: direito e política no Brasil

contemporâneo. RDE. Revista de Direito do Estado, v. 21, p. 82-122, 2011.

. Judicialização, Ativismo Judicial e Legitimidade Democrática. (Syn)Thesis (Rio de Janeiro), v. 5, p. 23-32, 2012.

BARTHES, Roland. A Aula. 14 ed. Trad. Leyla Perrone-Moises. São Paulo: Editora Cultrix, 1977.

BAUM, Laurence. A Suprema Corte Americana: uma análise da mais notória e respeitada instituição judiciaria do mundo contemporâneo. Rio de Janeiro: Forense, 1987.

BRASIL. Câmara dos Deputados. Câmara Notícias. Disponível em:

http://www2.camara.leg.br/camaranoticias/radio/materias/ultimas-noticias/404579--comissaode-seguridade-aprova-projeto-que-permite-desaposentacao-(0153). html. Acesso em: 12 de jul de 2014.

Câmara dos Deputados. Câmara Notícias. Disponível em:

http://www2.camara.leg.br/camaranoticias/radio/materias/ultimas-noticias/404579--comissaode-seguridade-aprova-projeto-que-permite-desaposentacao-(0153).html. Acesso em: 12 de jul de 2014.

Câmara dos Deputados. Câmara Notícias. Disponível em:

http://www2.camara.leg.br/camaranoticias/radio/materias/ultimas-noticias/416372-ldo-prevedespesas-de-r\$-49-bilhoes-com-desaposentacao.html. Acesso em: 12 de jul de 2013.

. Decreto $\mathrm{n}^{\circ} 3.048$ de 06 de maio de 1999. Aprova o Regulamenta da Previdência Social, e dá outras providências. Disponível em: http://www.planalto.gov.br/ccivil_03/decreto/d3048.htm. Acesso em: 10 de jul de 2014.

.Senado Federal. Portal Atividade Legislativa. Disponível em: http://www.senado.gov.br/atividade/. Acesso em: 10 de jul de 2013. 
.Senado Federal. Projeto de Lei do Senado n. 91/2010. Disponível em:

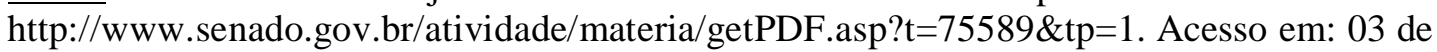
jul de 2014.

Supremo Tribunal Federal. Notícias STF. Disponivel em:

http://www2.stf.jus.br/portalStfInternacional/cms/destaquesNewsletter.php?sigla=newsletterP ortalInternacionalJurisprudencia\&idConteudo=271349. Acesso em: 23 de jul 2014.

. Superior Tribunal de Justica. Agravo Regimental em Embargos de Divergência no Recurso Especial n²79.889/AL. Rel. Min. Francisco Peçanha Martins, Rel. p/ acordão Min. Humberto Gomes de Barros. Julgado em 14 de agosto de 2002. Diário de Justiça de 07 de abril de 2003. Disponível em: http://www.stj.jus.br/SCON/. Acesso em: 01 de dez de 2014.

. Superior Tribunal de Justiça. Recurso Especial n ${ }^{\circ} .1334488-S C$, Rel. Min. Herman Benjamin. Julgado em 08 de maio de 2013. Diário de Justiça de 14 de maio de 2013. Disponível em: http://www.stj.jus.br/SCON/. Acesso em: 01 de dez de 2014. BORK, Robert H. Coercing virtue: the worldwide rule of judges, 2003. CAPPELLETTI, Mauro. Juízes Legisladores? Trad. Carlos Alberto Álvaro de Oliveira. Porto Alegre: Sergio Antonio Fabris Editor, 1999.

CERTEAU, Michel de. A Invenção do Cotidiano. 3 ed. Trad. Ephraim Ferreira Alves. Petrópolis: Vozes, 1998.

COMPARATO, Fábio Konder. O Poder Judiciário no regime democrático. Estudos avançados 18 (51). Instituto de Estudos Avançados da Universidade de São Paulo, 2004.

CAMBI, Eduardo. Neoconstitucionalismo e neoprocessualismo: Direitos fundamentais, políticas públicas e protagonismo judiciário. São Paulo: Editora RT, 2009.

CASTRO, Carlos Alberto Pereira de; LAZZARI, João Batista. Manual de Direito Previdenciário. 7. ed. São Paulo: LTR, 2006.

COELHO, Hamilton Antônio. Desaposentação: um novo instituto? In: Revista de Previdência Social, São Paulo, v. 228, p. 1130-1134, nov. 1999.

DORF, Michael. No litmus test: Law versus politics in the twentieth century, 2006, xix. DWORKIN, Ronald. O império do Direito. Trad. Jeffferson Luiz Camargo e versão técnica de Gildo Sá Leitao Rios. 2 ed. São Paulo: Martins Fontes, 2011.

FRIEDMAN, Barry. The politics of judicial review. Texas Law Review 84:257, 2005. FOUCAULT, Michael. A arqueologia do saber. Trad. Luis Felipe Baeta Neves. 7 ed. Rio de Janeiro: Forense Universitária, 2008.

. A Ordem do Discurso. Trad. Laura Fraga de Almeida Sampaio. 3 ed.São Paulo: Edições Loyola, 1996.

GARCIA NETO, Paulo Macedo. A influência do realismo jurídico americano no direito constitucional brasileiro, mimeografado, dissertação de mestrado apresentada na Universidade de São Paulo, sob orientação do Professor José Reinaldo Lima Lopes.

GIAMBIAGI, Fabio; PINHEIRO, Armando Castelar. Além da Euforia. Riscos e lacunas do modelo brasileiro de desenvolvimento. Rio de Janeiro: Elsevier - Campus, 2012. 
HART, Hebert L. A. O Conceito de Direito. 3. Ed. São Paulo: Fundação Calouste Gulbenkian, 2001.

IBRAHIM, Fábio Zambitte. Curso de Direito Previdenciário. 12 ed. Rio de Janeiro. Impetus, 2011.

Desaposentação. 2. ed. Niterói: Impetus, 2007.

KENNEDY, Duncan. Legal education and the reproduction of hierarchy. Journal of Legal Education 32:591, 1982.

MARTINEZ, Wladimir Novaes. Desaposentação. São Paulo: LTr, 2008.

NERY JUNIOR, Nelson; ABBOUD, Georges. Ativismo Judicial como Conceito Natimorto para Consolidacao do Estado Democratico de Direito: As razões pelas quais a justiça não pode ser medida pela vontade de alguém. In: DIDIER, Fredie Jr. et al. (Coord.), Ativismo Judicial e Garantismo Processual. Salvador: Editora Juspodivm, 2013. p. 525-546.

POSNER, Richard. Para além do Direito. São Paulo: Martins Fontes, 2009.

POST, Robert; SIEGEL, Reva Roe rage: democratic constitutionalism and backlash, Harvard Civil Rigts-Civil Liberties Law Review 42:373, 2007.

RAMOS, Elival da Silva. Ativismo Judicial- Parametros dogmáticos. São Paulo: Saraiva, 2010.

SADEK, Maria Tereza Aina. Poder Judiciário e democracia: uma visita a "O Poder Judiciário no regime democrático".In: BENEVIDES, Maria Victoria de Mesquita; BERCOVICI, Gilberto; MELO, Claudineu de. Direitos humanos, democracia e República: homenagem a Fábio Konder Comparato. São Paulo: Quartier Latin, 2009.

SILVA, Alexandre Garrido da. Minimalismo, democracia e expertise: o Supremo Tribunal Federal diante de questões políticas e científicas complexas. Revista de Direito do Estado.12:107, 2008.

STRECK, Lenio Luis; SALDANHA, Jânia Maria. Ativismo e Garantismo na Corte Interamericana de Direitos Humanos. In: DIDIER, Fredie Jr. et al. (Coord.), Ativismo Judicial e Garantismo Processual. Salvador: Editora Juspodivm, 2013. p. 395-428.

STRECK, Lenio Luis. O que é isto: decido conforme minha consciência? 3 ed. Porto Alegre: Livraria do Advogado, 2012.

VALLE, Vanice Regina Lírio do. Ativismo Jurisdicional e o Supremo Tribunal Federal. São Paulo: Juruá, 2009.

WOLFE, Christopher. La transnformacion de la interpretacion constitucional. Tradução de Maria Garcia de Casas y Sonsoles Valcárcel. Madri: Civitas, 1991. 